\title{
Seed Capital for Young Entrepreneurs since more than 25 Years
}

\author{
Jean-Pierre Vuilleumier*
}

Abstract: The WA de Vigier Foundation has supported start-up companies with a total of almost CHF 10 million since the late 1980s. And very successfully too: thanks to the seed money from Solothurn, the sponsored startups have provided hundreds of jobs.

Keywords: Seed money · Start-ups · WA de Vigier Foundation

At Supercomputing Systems AG, based in Zurich Technopark, 70 engineers, physicists, computer scientists and mathematicians, both women and men, develop innovative solutions for new products on behalf of customers. Biketec AG employs more than 160 staff at its factory in Huttwil, Bern, and produces more than 50,000 Flyer electric bikes a year.

The two companies are closely linked to the WA de Vigier Foundation in Solothurn, as each received start-up capital of $\mathrm{CHF}$ 100,000 . This help for young businesses was launched more than 25 years ago by entrepreneur William A. de Vigier. Since 1989 , the foundation has funded five startups every year to the tune of CHF 100,000 each; in addition, it also participates in the new companies with up to $10 \%$ of the share capital, to a maximum of CHF 10,000. To date, the foundation has granted almost CHF 10 million seed money for start-ups.

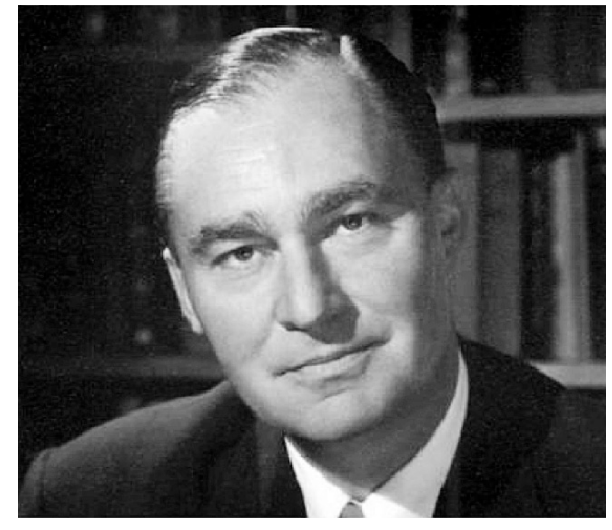

W.A. de Vigier

The track record is impressive: three quarters of the 93 sponsored companies are still in the market and have created hundreds of jobs. Among the most successful companies, in addition to Supercomputing Systems and Biketec, are biotech company Selexis from Western Switzerland and Schlieren/Zurich-based Molecular Partners. Another successful example is Snowpulse: Yan Berchten's company produces an avalanche-protection airbag and has been taken over by Swiss sportswear manufacturer Mammut. Even more successful were the founders of Glycart thanks to the acquisition of the company by Roche for CHF 235 million. Other promising companies awarded with the price money include GetYourGuide, L.E.S.S., Newscron, Climworks or GeoSatis.

\section{The Leadership Team}

Dr. Daniel Borer has been appointed president of the WA de Vigier Foundation last year, succeeding Moritz Suter.

In 2009, management of the foundation moved from Jean-Claude Strebel to Jean-Pierre Vuilleumier, who is strongly anchored in the start-up scene, as he is also managing director of investor association CTI Invest and is active as a coach for start-ups. He ensures that both the winners of the prize and the nominees attend the alumni meetings, benefit from the exclusive training and share experiences with each other.

Since 2010, the supporter of the year has also been honoured. This year, this prize went to Dr. Pascale Vonmont, ViceDirector of the Gerbert Rüf Foundation.

\section{Recent Changes}

A few more innovations were put in place a few years ago. The most important change is that the support is no longer limited to Swiss citizens; now foreigners who set up a company in Switzerland can also apply to the Young Entrepreneur Award of the WA de Vigier Foundation. In addition, the age limit has been raised to 45 .

This year has been a successful one for the WA de Vigier Foundation, with 230 applications, just short of the record of 250 last year.

Company founders who want to apply can register through the website at www.devigier.ch from July to the end of September every year.

Received: September 12, 2014

\footnotetext{
${ }^{*}$ Correspondence: J.-P. Vuilleumier

Managing Director

W. A. de Vigier Foundation

Sommerhaus

Untere Steingrubenstrasse 25

$\mathrm{CH}-4500$ Solothurn

Tel. +41792513209

E-mail: jpvuilleumier@devigier.ch
} 